\title{
Joggyakorlat
}

\author{
BenCze MátyÁs*
}

\section{A jogalkotó emberképének hatása a jogértelmezésre - Egy magyarországi kutatás tanulságai ${ }^{1}$}

\author{
Bírói gyakorlat - ártatlanság vélelme - jogalkalmazási problémák - \\ jogalkotó emberképe - alapelvek érvényesülése
}

Az utóbbi közel 10 évben, a PhD-fokozatom megszerzését követően, figyelmem egyre inkább a bírói gyakorlat problémáinak a szociológiai módszerekkel történő elemzése felé fordult. Ennek egyik motivációja az volt, hogy 2005-ig gyakorló bíróként dolgoztam, és a jogalkalmazás hétköznapjai rengeteg „nyersanyaggal” láttak el az ítélkezés problémáit illetően, másrészt pedig az, hogy a magyar jogtudományban átfogó módon ekkor még nem foglalkoztak a joggyakorlat szociológiai elemzésével.

A bírói gyakorlat problémáinak feltérképezése során három kérdést vettem alaposabban szemügyre. Az első az úgynevezett „mérce”-probléma, amelynek lényege, hogy több más társadalmi gyakorlattal szemben, rendkívül nehéz egzakt módon értékelni az itélkezés színvonalát, azaz nehéz felállítani annak az ideális gyakorlatnak a körvonalait, melyhez hozzá lehetne mérni a fennálló gyakorlatot. ${ }^{2} \mathrm{~A}$ habilitációs téziseim alapját képező könyvben megpróbáltam körvonalazni, hogy melyek lehetnek azok a mércék, amelyekhez érdemes viszonyítani a jelenlegi magyar bírói gyakorlatot. Arra a következtetésre jutottam, hogy magából az írott jogból, de még az a mögött meghúzódó igazoló elvekből sem tudunk állandó, stabil értékmérőket kinyerni, ugyanakkor azt elvárhatjuk a bíráktól, hogy legyenek az ítéleteik átgondolva, reflektáljanak

* Dr. Bencze Mátyás egyetemi docens, Debreceni Egyetem Állam- és Jogtudományi Kar Jogbölcseleti és Jogszociológiai Tanszék, bencze.matyas@law.unideb.hu.

1 E tanulmány a 2012. április 23-án, a Debreceni Egyetem Állam- és Jogtudományi Karán elhangzott habilitációs előadásom szerkesztett és kibővített változata.

2 A hazai jogirodalomban ezzel a kérdéssel még a világháború előtt részletesen foglalkozott Markó Jenő, aki szisztematikusan végig vette a mérceprobléma megoldása során felmerülő akadályokat, de mérceként csak egy homályosan körvonalazott többségi gyakorlathoz („hozzáértők minél nagyobb köre”) jutott el. Lásd MARKó Jenő: A jogalkalmazás tudományának alapjai. Magyar Jogászegylet, Budapest, 1936. 9. 
az ügyben felmerülő érvekre és ellenérvekre, mozgósítsák azt a tudást, amelyet bírói bölcsességnek szokás nevezni. ${ }^{3} \mathrm{E}$ mérce érvényességi körének meghatározása tanulmányom egyik általános megállapítása lesz.

A második célja a vizsgálódásaimnak a feltárt problémák csoportosítása, kategorizálása volt. Ebben a tekintetben a kategorizálás alapjának egyfelöl a bevett jogi érveknek (jogszabályok, bírói gyakorlat, jogdogmatika, mögöttes jogelvek) való megfelelést, másfelöl a bírói gyakorlat konzisztenciáját tekintettem. A harmadik témakör, amelyik jogszociológiai szempontból a legnagyobb jelentőséggel bír, az, hogy milyen okokat, tényezőket azonosíthatunk a feltárt problémák mögött. Könyvemben ezen okok összefoglaló bemutatására is kísérletet tettem. ${ }^{4}$

Az alábbiakban a bírói gyakorlat problémáinak egyik ilyen lehetséges okára koncentrálok, amelyet egy 2010-ben végzett kutatás során sikerült kollégáimmal azonosítani. ${ }^{5} \mathrm{~A}$ kutatás középpontjában az ártatlanság vélelmének magyarországi érvényesülése állt, melyet az elsőfokú büntetőbíróságok gyakorlatán keresztül vizsgáltunk. A kutatás során kollégáim és hallgatók segítségével az ország egész területéről közel 300 ügy ítéleteit dolgoztuk fel. Ennek során az ítéletek indokolásának szövegét alapos tartalomelemzésnek vetettük alá, továbbá próbáltuk az ítéleteket statisztikai szempontból is feldolgozhatóvá tenni (például, hogy milyen típusú bizonyítékokat használtak fel a bíróságok a leggyakrabban, miféle érveket vetettek be a bűnösségre vonatkozó mérlegelésük során stb.). Emellett a bírósági vezetőkön keresztül minden aktív magyar büntetőbírónak megküldtünk egy kérdőívet az interneten keresztül, melyre közel 70-en válaszoltak. Az on-line kérdöív a bírói gyakorlatra - direkt vagy indirekt módon - vonatkozó, különböző típusú kérdéseket, feladatokat, fiktív és megtörtént jogeseteket tartalmazott. E három módszer kombinációjának alkalmazásával igyekeztünk megtudni azt, hogy az ártatlanság vélelme oly módon érvényesül-e a bírói gyakorlatban, ahogyan azt egy európai demokratikus jogállam esetében elvárhatjuk, illetve ha vannak problémák, azok milyen okból erednek. Az ártatlanság vélelmét két szabály egymáshoz való viszonyán keresztül vizsgáltuk. Az egyik szabály az "in dubio pro reo", ${ }^{6}$ a másik pedig a bizonyítékok szabad értékelése. ${ }^{7}$ A megelőző kutatások ugyanis azt mutatták, hogy ez a két elv egymásnak vetélytársa: a bíróságok különösen akkor hivatkoznak előszeretettel a bizonyítékok szabad értékelésének elvére, amikor a rendelkezésre álló bizonyítékok nem bizonyítják kétséget kizáróan a vádlott bünösségét.

3 Bencze Mátyás: Elvek és gyakorlatok. Budapest, Gondolat Kiadó, 2011, 25-38.

4 Uo. 169-174.

5 A kutatás a Bolyai János Kutatási Ösztöndijj támogatásával valósult meg. Itt mondok köszönetet Kovács Ágnes doktorandusz hallgatónak és Ficsor Krisztina egyetemi tanársegédnek a bírói gyakorlat elemzésében nyújtott nélkülözhetetlen segítségükért.

6 1998. évi XIX. tv. (Be.) 4. § (2): „A kétséget kizáróan nem bizonyított tény nem értékelhető a terhelt terhére.”

7 Be. 78. § (3): „A bíróság és az ügyész a bizonyítékokat egyenként és összességükben szabadon értékeli, és a bizonyítás eredményét az így kialakult meggyőződése szerint állapítja meg." 


\section{A jogalkalmazás feltárt problémái}

Kutatásunk egyik (kimondottan a büntetőeljárás szociológiáját érintő) hipotézise az volt, hogy Magyarországon komoly problémák vannak az ártatlanság vélelmének érvényesülésével, itt azonban nem ennek igazolásával kívánok foglalkozni (ez lesz a tárgya a kutatás eredménye alapján készülö könyvemnek). Volt azonban egy másik, általánosabb jogszociológiai hipotézisünk is, mely szerint az ártatlanság vélelmével kapcsolatos problémák gyökere a bírák jogászi kultúrájában kereshető. Általánosan bevett nézet, hogy a volt szocialista országokban a jogalkalmazás problémái a szocialista korszakból átöröklött jogászi szocializációval, az onnan visszamaradt attitüdökkel és jogszemlélettel függenek össze, azaz egy sajátságos „posztszocialista” jogi kultúrában gyökereznek. ${ }^{8}$ Ebben a tanulmányban a második hipotézis igazolásával foglalkozom. Az eredményt megelőlegezve, arra jutottam, hogy a jogi kultúrának mint a jogalkalmazás minőségét meghatározó faktornak a súlyát, más tényezőkhöz viszonyított arányát és jelentőségét újra kell gondolni. Az ártatlanság vélelmének érvényesülésére irányuló kutatás azt igazolja, hogy jóval kevesebb múlik a bírák attitüdjén, szocializációján, szerepfelfogásán, mint azt korábban gondoltuk, ${ }^{9}$ és jóval több azon, hogy a jogalkotó miként szövegezi meg a jogszabályt, illetve milyen „bírókép" él a jogalkotóban, milyen képességeket tulajdonít a bíráknak.

Az ártatlanság vélelmével kapcsolatos kutatás egyik elsődleges, közvetlen eredménye az volt, hogy kimutattuk: a „tisztított” váderedményességi mutató 93\% körül mozog. Ez azt jelenti, hogy azokban az ügyekben, amelyekben a vádlott tagadta a cselekmény elkövetését, tehát ahol valódi tétje van a bizonyítási eljárásnak, a bíróságok 100 esetből 93 alkalommal bűnösséget kimondó döntést hoztak. Bár ez az arány önmagában nem biztos, hogy problémát jelez, a feltűnően magas eredményesség mégis okot adott arra, hogy megvizsgáljuk, milyen indokolással látták el a bíróságok az ítéleteiket. Abból indultunk ki, hogy amennyiben az indokolások nem meggyőzőek, azok logikailag, illetve tartalmilag aggályosak, akkor az ártatlanság vélelmének érvényesülésével is komoly problémák lehetnek. Miután tartalomelemzés módszerével megvizsgáltuk az ítéleteket, több olyan bevett és országosan elterjedt érvelési fordulatot (visszatérő paneleket) találtunk a bizonyítékok mérlegelésének indokolásaiban, amelyek jelentős mértékben csökkentik az indokolások meggyőző

8 A posztszocialista jogászi attitüdök jelentőségének bemutatásához lásd FEKETE Balázs: Kelet-Közép-Európa jogrendszerei, avagy vonzások és taszítások az elmúlt másfél évtizedben. In: Badó Attila - Bencze Mátyás (szerk.): Betekintés a jogrendszerek világába. Szeged, Studio Batiq, 2007, 145-157. A kelet-középeurópai jogalkalmazói attitűdök elemzésére KüHN, Zdeněk: Worlds Apart. Western and Central European Judicial Culture at the Onset of the European Enlargement, American Journal of Comparative Law 52: 2004, 531-568.; Galligan, Denis - MatczaK, Marcin: Strategies of Judicial Review. Exercising Judicial Discretion in Administrative Cases Involving Business Entities. Varsó, Ernst \& Young, 2005, 28-35.; ScHWARTZ, Bernard: The struggle for Constitutional Justice in Post-Communist Europe. Chicago and London, University of Chicago Press, 2000, 236-237.; FALKNER, Gerda - TREIB, Oliver: Three Worlds of Compliance or Four? The EU-15 Compared to New Member States. Journal of Common Market Studies 46 (2) 293-313.

9 Lásd Bencze: Elvek... i. m., 169-173. 
erejét. Az 1. táblázat tartalmazza azokat az érvelési hibákat, amelyek a tartalomelemzés során felszínre kerültek. ${ }^{10}$

1. táblázat

A bizonyítékok értékelésére vonatkozó indokolások logikai és tartami problémái

\begin{tabular}{|l|l|}
\hline Formális logikai problémák & Tartalmi problémák \\
\hline bizonyítás a bizonyítandóval & egyoldalú érvelés \\
\hline "Osztható" szavahihetőség & az érdemi mérlegelés hiánya \\
\hline formális bizonyítás & a szavahihetőség szelektív vizsgálata \\
\hline & a nyomozati vallomások túlsúlya \\
\hline & a bizonyítási teher rejtett átfordítása \\
\hline
\end{tabular}

A vizsgálat eredményeként feltárt problematikus érvelési sémák elterjedt alkalmazásából nem tudtunk más következtetést levonni, mint azt, hogy a bíróságok szilárd meggyőződése a bűnösség kérdéséről már azelött kialakul, ahogy számba vette és mérlegelte volna a rendelkezésre álló bizonyítékokat. A bíróság utólagosan tesz erőfeszítéseket arra, hogy a bizonyítékokat valamilyen módon hozzáigazítsa a bünösség kérdésében meghozott döntéséhez - akár olyan áron is, hogy az indokolás csupán formális lesz, elveszti a meggyőző erejét. Az ártatlanság vélelmével kapcsolatos probléma abban jelentkezik, hogy a Be. 78 . $\S(3)$ bekezdése szerint a szabad értékelés után, illetve az alapján kialakult meggyőződés szerint kell megállapítani a tényállást - az in dubio pro reo szabály figyelembevételével. A továbbiakban azonban nem ezeket az indokolási hiányosságokat vizsgálom, hanem azt kutatom, hogy miért szakad el a bírói gyakorlat ennyire a jogszabálynak a bizonyítékok mérlegelésére vonatkozó rendelkezésétől.

A bírák körében végzett kérdőíves felmérés egyik eleme nagyon tanulságos abból a szempontból, hogy miként értelmezi a bíróság a bizonyítékok szabad értékelését, és ennek mi a viszonya az in dubio pro reo szabályhoz. Az 1. számú diagramon az látszik, hogy a bírák, amikor arra kértük őket, hogy fontosságuk szerint rangsorolják a bizonyítási eljáráshoz kapcsolódó legfontosabb szabályokat, kiemelt jelentőséget tulajdonítottak az in dubio pro reo szabálynak (84,7\%-a a bíráknak szerepeltette a három legfontosabb szabály között). Ugyanakkor az in dubio pro reo szabály legfontosabb garanciája, a bizonyítékok közvetlen bírói vizsgálata csak az utolsó előtti helyre került (15,3\% említette az első három között).

10 A táblázatban szereplő formális-logikai és tartalmi indokolási problémák részletes kifejtésben megtalálhatóak a kutatás zárójelentésének (a továbbiakban: Zárójelentés) 50-71. oldalain; http://jog.unideb.hu/ documents/tanszekek/jogbolcseleti/publikcik/artatlansag_veleme_a_gyakorlatban.pdf. 


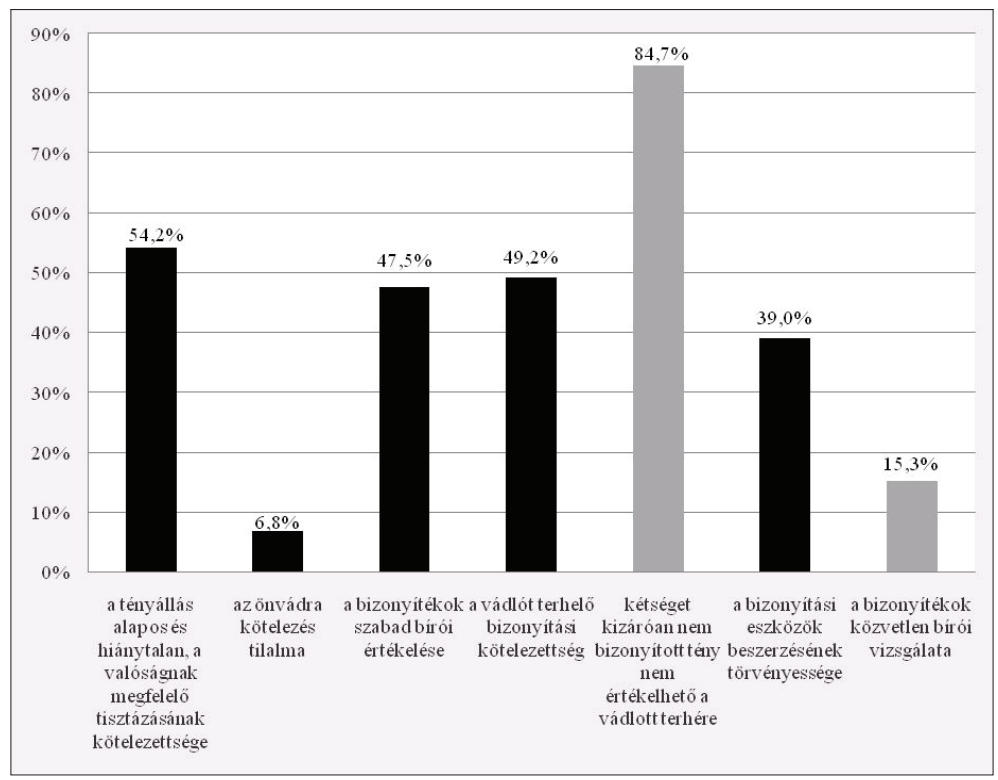

1. számú diagram - A bizonyításra vonatkozó szabályok „rangsora”

Mindez azt sugallja, hogy nem teljesen egyértelmü a megkérdezett bírák számára, mi a viszony ezen szabályok között: a bírói kar formálisan nagy jelentőséget tulajdonít az in dubio szabálynak, azonban ennek garanciáit már kevéssé veszi komolyan. Így tág tér nyílik a „szabad értékelésben” rejlő lehetőségek kihasználására, ami általában a vádlott elítélését jelenti akkor is, ha nincsenek a bíróság kezében kétséget kizáró bizonyítékok.

Ugyanez a bizonytalanság és az ennek talaján kialakult jogalkalmazási anomália figyelhető meg a kérdőívben szereplő esetek megoldásakor. A kérdőívben két esetet adtunk a bíráknak: az egyik a BH 1987. 391. eset „átirata”, amelynek lényege az volt, hogy csupán egyetlen (!) terhelő tanú szolgáltatott a vádlottal szemben bizonyítékot, a másodfokú bíróság mégis azt mondta, hogy ennyi bizonyíték alapján a vádlott elitélhető; a másik egy fiktív eset volt, melyben arra kérdeztünk rá a bíróktól, hogy ha a vádlottnak a tárgyaláson a bünösségét tagadó nyilatkozata és korábban a nyomozás során önmagára tett terhelő vallomása között ellentét áll fenn, és semmilyen más bizonyíték nincs, amelyik segítene az ellentmondás feloldásában, akkor melyik vallomást fogadná el. A bíróságok az első esetben 27\%-ban mondták volna ki bünösnek a vádlottat (a BH szerzőinek szándékával egyezően), a második esetben pedig a többség, majdnem $70 \%$ a nyomozás során tett vallomását használná fel a vádlottnak (2. számú diagram). 

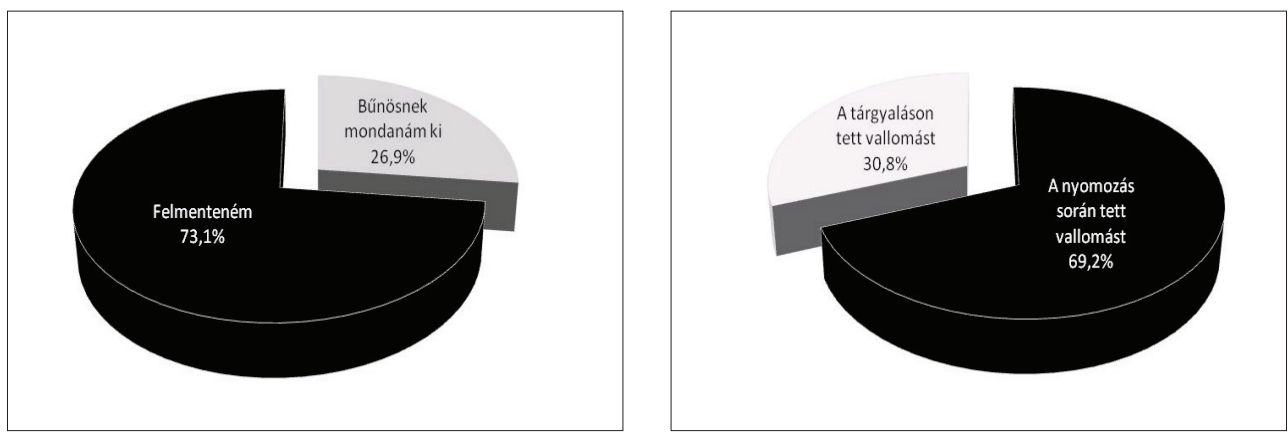

2. számú diagram - A bizonyítási szabályok bírói preferenciái az esetmegoldások tükrében

Az eredményekkel - az ártatlanság vélelmének érvényesülésétől elvonatkoztatva - az a legkomolyabb probléma, hogy olyan alapvető szabályok alkalmazásában látszik inkoherencia, amelyek egyébként a bírói gyakorlat fundamentumát kellene, hogy képezzék. Mindkét eset megoldásakor ésszerü indokok nélkül szorul háttérbe az in dubio pro reo szabály a bizonyítékok szabad értékelésével szemben. A második eset jól jelzi továbbá, hogy a bizonyítékok közvetlen megvizsgálása tényleg nem áll a bírói preferencia élén.

\section{A problémák okainak hagyományos magyarázata}

A magyar büntetőeljárás sajátosságaira koncentráló magyarázatok szerint a háttérben a bíróságok „vádközpontúsága” áll. Több szerző számtalan alkalommal megírta már, hogy a bíróságok normál müködéséhez a vádlott elítélése tartozik hozzá, és azt kell alaposan megindokolni, az a kivétel, ha valakit felmentenek. A bírák nagyon nagy mértékben támaszkodnak az ügyészség által összeállított iratokra, azt olvassák el, abból készülnek fel, és a bizonyítás levezénylése az akta átolvasása során szerzett benyomásaik alapján történik. ${ }^{11} \mathrm{~A}$ továbbiakban ezt nevezhetjük az „első benyomás" hipotézisének.

E hipotézis tesztelésére egy amerikai kutatásból átvett tesztet alkalmaztunk, ${ }^{12}$ mely három egyszerünek látszó kérdésből áll:

Egy napszemüveg és egy hozzá tartozó tok összesen 1100 forint. A napszemüveg 1000 forinttal kerül többe, mint a tok. Hány forintba kerül a tok?

Egy tengeri öbölben egy olajfolt növekszik. A folt minden nap kétszeresére nő. Ha 48 nap alatt lepi el a teljes öblöt, akkor hány napig tartott, amíg a felét borította be?

11 A szakmai kritikák összefoglaló ismertetésére lásd Zárójelentés: 28-34. Az ezeken az oldalakon ismertetett elemzések zöme a jogalkalmazók gondolkodásmódját tette felelőssé a kialakult helyzetért.

12 A kísérlet leírására és az eredmények elemzésére lásd GUTHRIE, Chris - RACHLINSKI, Jeffrey J. - WISTRICH, Andrew J.: Blinking on the bench: how judges decide cases, 93 Cornell Law Review (2007), 1-44. 
Ha 5 gép 5 perc alatt 5 karkötőt gyárt le, akkor hány percig tart, amíg 100 gép legyárt 100 karkötőt?

A kérdésekben közös, hogy mindegyikre van egy intuitív, az első benyomáson alapuló válasz, amely azonban mindhárom esetben hibás (100, 24 és 100). Amenynyiben ezek a hibás válaszok fölénybe kerülnek, az azt jelenti, hogy a bírák hajlamosak az első benyomásuk alapján dönteni, és nem fordítanak időt és energiát arra, hogy azt további teszteknek, ellenőrzésnek vessék alá. Az eredmények azonban azt mutatták, hogy nemzetközi összehasonlításban a magyar bírák meglehetősen jó eredményt értek el ezen a teszten. Az összehasonlításban csupán két amerikai elit egyetem hallgatói előzték meg őket (3. számú diagram).

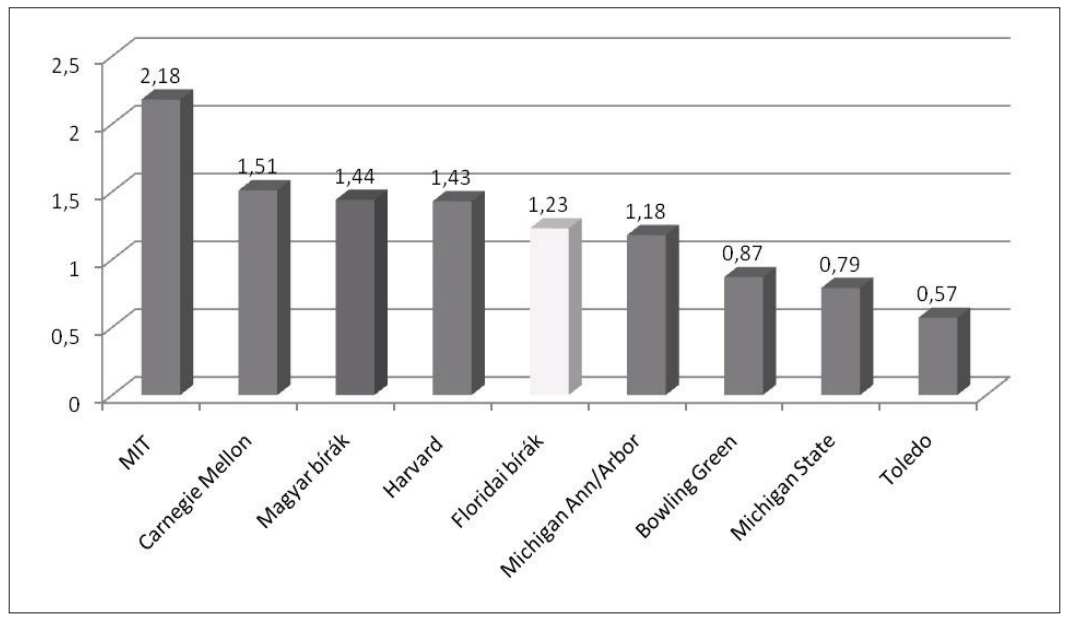

3. számú diagram - Az „első benyomás” döntést befolyásoló erejének összehasonlító vizsgálata

Egyetlen vizsgálat eredménye természetesen nem perdöntő, de mindenképpen gyengíti az „első benyomás” hipotézisét, és ez motivált abban, hogy a jogászi kultúrán, „a szokás hatalmán” vagy a bírák hozzáállásán kívül máshol is keressem a jogalkalmazással összefüggő problémák gyökereit. Amint említettem, a kelet-középeurópai bírói gyakorlatot elemző munkák általában viszonylag kevés figyelmet fordítanak a jogszabályok és a bírói döntések közötti összefüggésre, a hibás gyakorlatot elsősorban a bíráknak róják fel anélkül, hogy megvizsgálnák, miképpen formálta, befolyásolta a bírák ítélkezését a vonatkozó jogszabály megfogalmazási módja, illetve a jogalkotó emberképe, amelyre a jogszabályok megírásakor tudatosan vagy reflektálatlanul támaszkodott. ${ }^{13}$

13 Lásd a 9. sz. lábjegyzetben felsorolt elemzéseket. 


\section{Egy alternatív magyarázat}

A büntetőeljárási magyar szakirodalomban már felhívták arra a figyelmet, hogy az ártatlanság vélelme elvének gyakori megsértése és a bizonyítást vezérlő szabályok komolyan vételének hiánya nem csupán a bírói attitüdökre vezethetők vissza, hanem összefüggésben lehetnek a jogszabályok szövegezésével és a jogalkotó mögöttes emberképével. ${ }^{14} \mathrm{Ez}$ az állítás azért lehet meglepő, mert nem a nyilvánvaló jogalkotási hibákra vonatkozik, hanem azokra a bevett és mindenki által alapvetőnek tekintett szabályokra, melyekről az a kép alakult ki, hogy a jogállami büntetőeljárás évszázados garanciáinak letisztult megfogalmazásai. Az ártatlanság vélelmének érvényesülését illetően éppen azt a már idézett két szabályt emelhetjük ki, amelyek a kutatásaink homlokterében álltak: a Be. 4. § (2) bekezdését, mely szerint „a kétséget kizáróan nem bizonyított tény nem értékelhető a terhelt terhére", és a Be. 78 . § (3) bekezdése, amelynek alapján „A bíróság és az ügyész a bizonyítékokat egyenként és összességükben szabadon értékeli, és a bizonyítás eredményét az így kialakult meggyőződése szerint állapítja meg". Mi is lehet a probléma e két kardinális rendelkezéssel?

Az előbbi, első ránézésre teljesen korrekt és az ártatlan vádlott érdekeit maximálisan szolgáló szabály kimondja, hogy csak a kétséget kizáróan bizonyított tényt lehet a vádlott terhére figyelembe venni. Úgy tủnhet, ez a szigorú rendelkezés szolgálja leginkább az ártatlanok védelmét: a teljes bizonyosság követelménye garantálja, hogy egyetlen ártatlant se ítéljenek el. Ha azonban a bíróságok valóban komolyan vennék ezt a szabályt, akkor szinte soha nem ítélhetnének el senkit. Egy szemernyi kétség mindig marad, már csak azért is, mert tudásunk a világról távolról sem teljes, léteznek olyan fizikai, kémiai, biológiai, pszichológiai összefüggések és törvényszerüségek, amelyeket még nem fejtettünk meg. A matematikai bizonyosság elérése a matematikán (és a tiszta logikán) kívül lehetetlen. Tudjuk, hogy Newton törvényei is bizonyosnak látszottak - ameddig azokat Einstein új paradigmája fel nem váltotta. Miért lehetne tehát egy bíró száz százalékig biztos a dolgában a ténymegállapítás során? A tanúkat érzékszerveik, emlékezetük gyengeségei megtréfálhatják, a tárgyi bizonyítékok önmagukban általában nem mondanak sokat, a szakvélemény megítélésének kérdésében a bíró a legtöbb esetben nem kompetens. De még ha egy adott ügyben több egymást erösítő, önmagában is elsöprő erejü közvetlen bizonyíték létezik a tényállás tárgyi oldalára nézve, biztosak lehetünk-e abban, hogy a tudati oldal felöl bizonyossággal rendelkezünk? Honnan tudjuk, hogy nem lépett-e fel a vádlott elmemüködésében heveny, gyorsan elmúló zavar, amely egyébként beszámíthatatlanságot eredményez (vagy nem állt-e hipnózis hatása alatt)? A példák természetesen extrémek, de arra jól rávilágítanak, hogy a szigorú értelemben vett teljes bizonyosság nem érhető el a bizonyítási eljárásban.

A szabály tehát maximalista, olyan, szinte emberfeletti megismerési és átgondolási képességet követel meg a bíráktól, amely a valóságban nem létezik. A jogalkotó mögöttes, antropológiai előfeltevése tehát az, hogy a jogalkalmazó számára nem

14 Lásd BÁRD Károly: A büntető hatalom megosztásának buktatói. Budapest, KJK, 1987, 210.; Bócz Endre: Büntetőeljárási jogunk kalandjai. Budapest, Magyar Hivatalos Közlönykiadó, 2006, 144. 
okoz semmilyen problémát a matematikai bizonyossággal határos, sőt azt elérő bizonyosságú tényállás-megállapítás. A kutatás eredeti célja szempontjából fontos, hogy nem csupán értelmetlen, hanem veszélyes is a jogszabályok ilyen típusú megfogalmazása. Egy ilyen mérce bevezetése ugyanis azt eredményezi, hogy a bíróságok nem is veszik (mert nem is vehetik) azt komolyan. Ezen a talajon pedig, biztos mércék híján könnyen szárba szökkenhet akár egy olyan gyakorlat is, amely annyira leszállítja az elítéléshez szükséges bizonyítottság szintjét, ami már távolról sem elégíti ki a jogállami követelményeket. Az elérhetetlen eszmények közvetlen érvényesítésének szándéka pedig az antidemokratikus és voluntarista politikai berendezkedések egyik jellemzője. ${ }^{15}$

Hasonló jellegủ a probléma a másik szabállyal, a szabad értékelést előíró jogi rendelkezéssel. Ez a szabály általános iránymutatásként írja elő a bíró számára a szabad mérlegelést, amelyet a büntetőeljárás más bizonyítási szabályai is csupán rendkívül csekély mértékben korlátoznak. A bizonyítékok szabad értékelésének elve mögött az a helytálló felismerés húzódik meg, hogy egy olyan összetett és bonyolult tevékenységet, mint a bizonyítékok összevetése, súlyozása nem lehet általános szinten formalizálni, nem lehet valamilyen algoritmust találni az egymást követő lépésekre, melyet aztán jogi rendelkezések formájába öntenénk. Ennek lehetetlenségét jól mutatják a formalisztikus, az egyes bizonyítékfajtákhoz előre meghatározott súlyt rendelö bizonyítási rendszerek abszurditásai. Ugyanakkor az elv tükrözi azt az optimizmust is, amely szerint a racionális emberi elme mindig képes megtalálni az adott esetre helyes megoldást, ha az értékelő tevékenységet nem szorítjuk korlátok közé. Úgy túnik, a magyar jogalkotó ilyen felszámolandó korlátnak tekintette (és tekinti a mai napig) a mérlegelés indokolásának kötelezettségét is, mivel szinte teljesen kiüresítette azt. A Be. 258. § (3) bekezdésének d) pontja a bizonyítékok értékelésének indokolásáról szűkszavúan csak annyit ír, hogy a határozat azt „összefüggően tartalmazza”, de ezen túl semmilyen módon nem rögzíti, hogy mi minősül elégséges indokolásnak.

Kérdés, hogyan áll hozzá a bírói gyakorlat a szabad értékelés rendkívül általános szabályához, miként használja azt fel a bizonyítékok értékelése során. Frederick Schauer egyik cikkében amellett érvel, hogy nem jelent problémát, ha a jogalkotó valamely jogterületet csupán általános szabályokkal igazgat, mivel a bírói gyakorlat úgyis ki fogja dolgozni a pontos alkalmazáshoz szükséges standardokat, megkülönböztetéseket, belső mércéket, azaz részletezi az általános szabályt. ${ }^{16}$ Álláspontom szerint olyan szabályok esetében (mint például a magyar jogban a kártérítés „mesterszabálya"), melyek a bíró által megítélendő életviszonyokra vonatkoznak, ez a meglátás helyes. A magyar kártérítési "mesterszabályt” is számos bírói döntés pontosította (például az orvosi vagy a jogalkalmazói károkozás körében). Azonban Schauer ezt a tézisét univerzális igazságként fogalmazta meg, és nem számolt azzal, hogy

15 Bővebben erről lásd BENCZE Mátyás: A bizonyítékok értékelésének összehasonlító vizsgálata a tisztességes eljárás szempontjából. In: Badó Attila (szerk.): A bírói függetlenség, a tisztességes eljárás és a politika. Budapest, Gondolat Kiadó, 2011, 218-235.

16 Lásd Schauer, Frederick: The Convergence of Rules and Standards, 38 New Zealand Law Review (2003), 303. skk. 
vannak olyan szabályok, amelyek magára a bírói tevékenységre, a bírói jogalkalmazási tevékenységre vonatkoznak. Ezekben a speciális esetekben nem érvényesül a szükségszerủ konkretizálás folyamata. A konkretizálás célja, funkciója ugyanis az, hogy döntési támpontokat hozzon létre, és megkönnyítse a bíró számára a meghozott határozat indokolását. A konkrétabb normák ugyanis közelebb állnak az adott eset tényeihez, ezért a felhasznált jogi érvek és az eset közötti kapcsolat is sokkal világosabb lehet az adott ügyben érintettek, illetve a potenciális hallgatóság egésze számára. Ha tehát a bíróságok korábbi esetekre vonatkozóan már tisztázták az általános szabály jelentését, akkor az újabb ügy bírójának is könnyebb dolga van, amikor az adekvát jogi indokokat prezentálja: a korábbi bírói döntések révén ezek már legitim jogi indoknak minősülnek. Az érvelés tehermentesítése adja tehát az értelmét a konkrétabb döntési támpontok kidolgozásának.

Azonban, ha éppen a szabály általános megfogalmazása könnyíti meg a bíró számára az indokolást, akkor a bírói gyakorlat nem fog arra törekedni, hogy részletezze az általános szabályt. Ahhoz füződik ugyanis érdeke, hogy minél könnyebben meg tudja indokolni az általa elfoglalt álláspontot. Alátámasztja ezt a megállapítást az a tény, hogy a Be. 78. § (3) bekezdéséhez nem is kapcsolódik konkretizáló bírósági határozat. A szabad mérlegelés elve így, ahogy azt több megvizsgált indokolásban is láttuk, akkor került explicit módon említésre, ha maga a bíró is érezte, hogy viszonylag kevés terhelő bizonyíték állt a rendelkezésére, azonban ennek ellenére mégis bünösséget kimondó ítéletet hozott. ${ }^{17}$ Így a bizonyítékok szabad értékelésének általános szabálya egyfajta „aduként” kezd müködni, melynek segítségével könnyen felülírhatóak más szabályok (mint például az in dubio pro reo szabály), a gyakorlat könnyen divergálni kezd, és a lehetséges támpontok esetlegessé válnak.

A fentiek következtében, amikor a bíró döntést hoz a büntetöügyben a vádlott bünösségét illetően, akkor ésszerüen részletes értékelési és indokolási szabályok hiányában más támpontokat fog keresni. A büntetőeljárás struktúrájából pedig az következik, hogy sokkal könnyebb a nyomozó hatóság és az ügyész által összeállított iratanyagra és magára a vádiratra támaszkodni, amelyek viszont „természetüknél fogva" a bünösség megállapítása felé orientálják a bírót (máskülönben nem nyújtotta volna be az ügyész a vádat). ${ }^{18}$ Tehát nem az „első benyomás” hatása miatt támaszkodnak a bírák a vádra, hanem mert ez jelent számukra kézzelfogható támpontot a bünösség kérdésének megítélésében.

Ilyen módon a bizonyításra vonatkozó túlságosan általános, illetve maximalista szabályok könnyen éppen ellenkező hatást gyakorolnak a jogalkotó „eredeti szándékához" képest. Nem hogy védenék az ártatlan vádlott érdekeit, hanem éppenséggel azt teszik lehetővé, hogy minél egyszerübben, könnyebben lehessen elítélni valakit. Nem véletlen az, hogy más jogrendszerekben, ahol felismerték ezt a veszélyt, próbálják ésszerű módon mederben tartani az értékelési folyamatot. A hozzánk leginkább hasonló jogi kultúrájú Németországban például a büntetőeljárási jog kiemelt jelentő-

17 Lásd Zárójelentés: 54-56.

18 Bővebben erről lásd BENCZE Mátyás - ZsıRos Zsolt: A bűnösség vélelme - a „Buktai-ügy” tanulságai. In: Szabadfalvi József (szerk.): Amabilissimus. A legszeretetreméltóbbak egyike. Loss Sándor Emlékkönyv. Debrecen, a Debreceni Egyetem Állam- és Jogtudományi Karának kiadványa, 2005, 151-165. 
séget tulajdonít a részletes indokolásnak: ez ugyanis rákényszeríti a bírót arra, hogy olyan módon értékelje a bizonyítékokat, amelyről világosan és meggyőzően számot is tud adni. Ennek megfelelöen az indokolásnak olyannak kell lenni, hogy az az ügy ismerete nélkül is világosan érthető legyen, ${ }^{19}$ a tények puszta felsorolása nem minősül indokolásnak, az értékelés prezentálásával szemben követelmény, hogy logikus és koherens legyen. Az indokolás akkor minősül elégtelennek, ha a bíróság egy adott tény vonatkozásában nem számol be arról, hogy miért tekintette bizonyítottnak, vagy miért vetette azt el. További fontos indokolási előírás, hogy a bírónak nem csupán a saját meglátásának helyessége mellett kell érvelnie, hanem mérlegre kell tennie az azzal szemben felhozott ellenvetéseket. Ez a tanúvallomások esetében pl. azt jelenti, hogy a releváns vallomásokat az ítéletben részletesen kell értékelni, föleg, ha az azokban előadottakkal ellentétes tények lehetősége is felmerül. ${ }^{20}$

\section{4. Általános következtetések}

Összegzésként elmondható, hogy igazolódott az a régi - bár korábban inkább a laikusok vonatkozásában emlegetett - jogszociológiai tétel, mely szerint a jog szövege nem csupán semleges közvetítő közeg, amelynek megértése, alkalmazása az átlagos értelem számára nem jelenthet problémát. A túlságosan elnagyolt, általánosságokban fogalmazó, vagy éppen maximalista elvárásokat támasztó rendelkezések nem kizárólag a laikusokat, hanem a jog professzionális müvelőit is tévútra vezethetik. A jogalkotásnak ez a problémája nem csak a jogalkotói hanyagság, átgondolatlanság következménye lehet. Véleményem szerint azzal is összefügg, hogy a jogalkotó emberképe latens módon befolyásolja a jogalkalmazást, még úgy is, hogy sem a jogalkalmazó, sem a jogalkotó nincs tisztában azzal, milyen antropológiai előfeltevésre is támaszkodik. A büntetőeljárás két elemzett szabálya mögött olyan jogalkotói emberkép bontakozik ki, mely egy szinte emberfeletti képességekkel rendelkező jogalkalmazót feltételez, aki mindig képes 100\%-os bizonyosság elérésére, ha bünösséget állapít meg, és szinte tévedhetetlen a bizonyítékok értékelése során. Ennek az emberképnek reflektálttá tétele és kritikája az egyik legfontosabb kihívása a hazai jogtudománynak. Az ésszerüen részletes, életközeli, könnyen betartható és számonkérhető mércék feltárása és bevezetése nem a bírói mérlegelési szabadság csonkítását jelenti, hanem az emberi megismerőképesség határainak figyelembevételét, amely az érett jogrendszerek sajátja. ${ }^{21}$

A jogszociológia számára pedig az a következtetés adódik, hogy a bírói gyakorlat problémái nem mindig csupán a bírói gyakorlatra vezethetők vissza, hanem az eddigieknél nagyobb figyelmet kell fordítani a külső tényezők vizsgálatára is. A jogalkalmazás és a jogalkotás minőségének vizsgálata tehát nem választható el egymástól:

19 Lásd Cape, Ed - Namoradze, Zaza - Smith, Roger - Spronken, Taru: Effective Criminal Defence in Europe. Antwerp - Oxford - Portland, Intersentia, 2010, 290.

20 Uo. 291.

21 Vö. Clermont, Kevin M.: Procedure's Magical Number Three: Psycholigical Bases for Standards of Decision. 72 Cornell Law Review, 1986, 1155. 
a bírói gyakorlat színvonala nem csak olyan általános és néha homályos kategóriáktól függ, mint a „bírói attitűdök”, ,jogászi kultúra” vagy „jogi hagyományok”, hanem olyan jól behatárolható, konkrét és kezelhető strukturális feltételektől, mint a szabályozás megalapozottsága, átgondoltsága és a szabályozási tárgy természetének, illetve a jogalkalmazó reális képességeinek figyelembevétele. A minőségi jogalkotás megvalósulásához természetesen szükséges a megfelelő szakapparátus és a jogalkalmazók bevonása is. Másfelöl arra is ügyelni kell, hogy a szabályozás az ésszerủ mértékig legyen részletes, az ne jelentse a bírói mérlegelés szükségtelen és egy jogállamban megengedhetetlen korlátozását. A határok megállapítása egy olyan összetett probléma, amely további kutatásokat igényel.

\section{Abstract}

The paper tries to answer the question whether the principle of 'presumption of innocence' is applied appropriately and consistently in the practice of Hungarian judges. In 2010 we studied the judicial activity of a chosen number of Hungarian judges by analyzing the text of roughly 300 judgements of Hungarian courts and by carrying out an on-line survey among Hungarian judges. As a primary result we could identify some major deficiencies concerning the application of the principle. The other lesson we learnt from the research is that serious principles play their part only if the legislator at the drafting of the law takes the actual knowledge and skills of the law applier into account. 